www.jmscr.igmpublication.org

Impact Factor (SJIF): 6.379

Index Copernicus Value: 79.54

ISSN (e)-2347-176x ISSN (p) 2455-0450

crossrefDOI: https://dx.doi.org/10.18535/jmscr/v6i9.120

Journal Of Medical Science And Clinical Research

IGM Publication

An Official Publication of IGM Publication

\title{
Analgesic Activity of Asoka - Saraca asoca (Roxb.) de Wilde
}

\author{
Authors \\ Asha S Raj ${ }^{1 *}$, Dr Sara Monsy Oommen ${ }^{2}$ \\ ${ }^{1}$ PG Scholar, Department of Dravyagunavijnanam, Govt. Ayurveda College, Tripunithura \\ Email:drashasraj@gmail.com, Ph.no: 9072500690 \\ ${ }^{2}$ Professor, Department of Dravyagunavijnanam, Govt. Ayurveda College, Tripunithura \\ Email:drsaramoncyoommen@gmail.com,Ph.no: 9446024624
}

\begin{abstract}
The drug, Asoka - Saraca asoca (Roxb.) de Wilde. has been included under Vedanasthapana Mahakashaya mentioned in Shatvirechana shatasriteeya by Acharya Charaka. Analgesic activity of drug has been mentioned in the classics. It is extensively used as arishta in the management of various anila vedana in Udavartha. In order to ascertain the pharmacology of analgesic action this study has been done in a reverse pharmacological aspect. Analgesic activity has been assessed using acetic acid induced writhing method in female Wistar Albino rats. The writhing syndrome was established by intra peritoneal injection of $0.25 \% \mathrm{v} / \mathrm{v}$ acetic acid in normal saline $(0.4 \mathrm{ml} / 200 \mathrm{~g}$ b.wt.). The test drug and standard drug, will be administered to rats 60 minutes prior to injection of acetic acid. The analgesic activity is expressed as percent inhibition of writhing. Analgesic study was found significant in effective and double effective dose of the test drug compared to control. Thus, it confirms the analgesic activity of kashaya of stem bark of Asoka - Saraca asoca (Roxb.) de Wilde.
\end{abstract}

Keywords: Asoka - Saraca asoca (Roxb.) de Wilde, Analgesic activity, CNS depressant activity.

\section{Introduction}

Ayurveda is the indigenous system of medicine in India. The word itself means "knowledge for longevity". It explains chikitsa (treatment - mode to attain health) as a conglomeration of chatushpada's (four limbs). After Vaidya (physician), dravya (drug) has been considered as the prime object responsible for successful treatment. Pharmacological categorization of drugs can be explored for the first time from the Charaka Samhita, Shadvirechana Shatasriteeya Adhyaya. In the chapter about 50 groups of drugs with specific indications are grouped as Mahakashaya and explained in detail.
Asoka - Saraca asoca [Roxb] de Wilde; has been included in the Vedanasthapana mahakashaya mentioned by Acharya Charaka. Acharya Chakrapani explains that Vedanasthapana dravya's are those which alleviates vedana and results in prakrutisthapana. Asoka has been used as arishta formulation, in clinical conditions like dysmenorrhea, as a spasmodic pain reliever. Even though it belongs to the 'Vedanasthapana mahakashaya' it's usage as kashaya is not at all popular in clinical practice. Hence a reverse pharmacological study has been undertaken to validate the analgesic effect of kashaya of stem bark of Asoka - Saraca asoca (Roxb.) de Wilde. 


\section{Materials and Methods}

Materials used

Female Wistar albino rats weighing 150 to $200 \mathrm{~g}$, kashaya of stem bark of Saraca asoca (Roxb.) de Wilde., distilled water, feeding cannula, gloves, weighing balance, feeding bottle, syringes \& $0.4 \mathrm{ml}$ of $0.25 \%$ acetic acid.

\section{Preparation of test drug}

The stem bark of Asoka - Saraca asoca (Roxb.) de Wilde were collected from authentic source and washed with water to remove impurities and dried. The dried stem bark were crushed coarsely. The test drug was prepared boiling 1 pala $(48 \mathrm{~g})$ of coarsely crushed stem bark of Saraca asoca (Roxb.) de Wilde. in 16 parts (768litre) of water over mild fire and reduced to 1/8 part (96litre) of the original quantity. Then the test drug was filtered to ensure it is free flow thorough the oral gavage.

\section{Dose of the test drug}

Human dose for kashaya is $48 \mathrm{ml}$ as per AFI. The dose of the drugs were calculated by extrapolating the therapeutic dose to effective rat dose by using the conversion factor given by Paget and Barnes Table (1964), which is based on the body surface area ratio. Conversion factor for rat dose corresponding to the human dose is 0.018 .

Animal dose $=$ Human dose $\times 0.018$ for $200 \mathrm{~g}$ rat $=48 \mathrm{ml} \times 0.018=0.864 \mathrm{ml} / 200 \mathrm{~g}$ rat $=0.864 \mathrm{ml} / 200 \mathrm{~g}$ of rat

For analgesic study

The drug is given in the following doses, $1 / 2 \mathrm{X}, \mathrm{X}$, $2 \mathrm{X}$ where ' $\mathrm{X}$ ' represents the calculated effective dose of the test drug.

\section{Dose of the standard drug}

The dose of Mefenamic acid for human was found to be $500 \mathrm{mg}$. The dose of Mefenamic acid to be administered in $200 \mathrm{gm}$ of rats was calculated as per Paget and Barns table:

Dose of Mefenamic acid for rats $=500 \times 0.018$

$$
=9 \mathrm{mg} / 200 \mathrm{~g} \mathrm{~b} . \mathrm{wt}
$$

$500 \mathrm{mg}$ of Mefenamic acid tablet was dissolved in $50 \mathrm{ml}$ water, so that $1 \mathrm{ml}$ of suspension contains $10 \mathrm{mg}$ of drug.

Dose of Mefenamic acid in $1 \mathrm{ml}$ suspension = $50 \mathrm{mg}$

Dose of suspension for $200 \mathrm{~g}$ rat $=9 / 10 \times 1=0.9 \mathrm{ml}$ Dose of suspension was calculated according to the weight of the rat.

\section{Design of animal experiment}

The study was conducted in 30 female Wistar albino rats of about $150-200 \mathrm{~g}$. Initially test drug was administered and after $1 \mathrm{hr}$ writhing was induced by the i.p administration of $0.4 \mathrm{ml}$ of $0.25 \% \mathrm{v} / \mathrm{v}$ of acetic acid. Animals showed characteristic writhing response within 3 minutes and number of writhes were counted for 15minutes. Animals which won't show any response within 3 minutes were discarded from the study. ${ }^{[1]}$

\section{Grouping of animals}

The animals were divided into 5 groups comprising 6 rats in each group. Group A (Control) received normal saline at a dose of $2 \mathrm{ml} / 200 \mathrm{~g}$ b.wt. Group B (Standard) received standard drug Mefenamic acid 9mg/200g b.wt. Test groups received half the calculated effective dose(TG1), calculated dose(TG2) and double the calculated dose(TG3) of the test drug. Drug were done as a single dose through oral route.

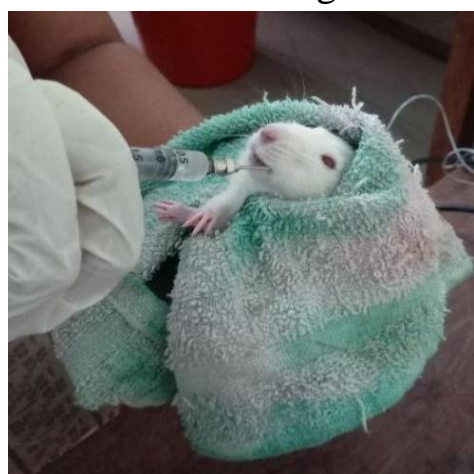

Fig: $1 \& 2$ Handling \& Administration of test drug to rat using oral gavage 
Table: 1 Grouping of animals for analgesic study

\begin{tabular}{|l|c|c|}
\hline Groups & Treated with & $\begin{array}{c}\text { Dose of drug } \\
\text { administered }\end{array}$ \\
\hline Group A & Normal saline & $2 \mathrm{ml} / 200 \mathrm{~g}$ b.wt \\
\hline Group B & Mefenamic acid & $9 \mathrm{mg} / 200 \mathrm{~g}$ b.wt \\
\hline Test Group 1 & $\begin{array}{c}\text { Kashaya of stem bark of Saraca asoca } \text { (Roxb) } \\
\text { de Wilde [1/2X] }\end{array}$ & $0.432 \mathrm{ml} / 200 \mathrm{~g}$ b.wt \\
\hline Test Group 2 & $\begin{array}{c}\text { Kashaya of stem bark of Saraca asoca } \text { (Roxb) } \\
\text { de Wilde [X] }\end{array}$ & $0.864 \mathrm{ml} / 200 \mathrm{~g}$ b.wt \\
\hline Test Group 3 & $\begin{array}{c}\text { Kashaya of stem bark of Saraca asoca } \text { (Roxb) } \\
\text { de Wilde[2X] }\end{array}$ & $1.728 \mathrm{ml} / 200 \mathrm{~g}$ b.wt \\
\hline
\end{tabular}

\section{Procedure}

Analgesic activity of test drug will be assessed by employing acetic acid induced writhing method in rats. The writhing syndrome was established by intra peritoneal injection of $0.25 \% \mathrm{v} / \mathrm{v}$ acetic acid in normal saline $(0.4 \mathrm{ml} / 200 \mathrm{~g}$ b.wt.). The test drug and standard drug, will be administered to rats 60 minutes prior to injection of acetic acid. The analgesic activity is expressed as percent inhibition of writhing. The animals react with a characteristic stretching behaviour which is called writhing. It is characterized by a wave of contractions in abdominal muscles followed by hind limb extension. The response can be elicited as a stretch, tension to one side, extension of hind legs, contraction of the abdomen so that the abdomen of rat touches the floor, turning or twisting the trunk. The no. of writhes will be counted for 15 minutes time, commencing just 3 minutes after the intra-peritoneal administration of acetic acid solution. The animals which doesn't show any response after 3minutes will be discarded from the study. ${ }^{[2]}$

\section{Results}

Writhing is defined as a stretch, tension to one side, extension of hind legs, contraction of the abdomen so that the abdomen of rat touches the floor, turning or twisting the trunk. The animals did not always give full writhing, sometimes they started to give but they did not complete it. This unfinished writh was counted as half-writhing. Hence, two half writhes were taken as one complete writhing.

Figure: 3 Animal showing initiation of writh - stretching body \& extension of hind limbs

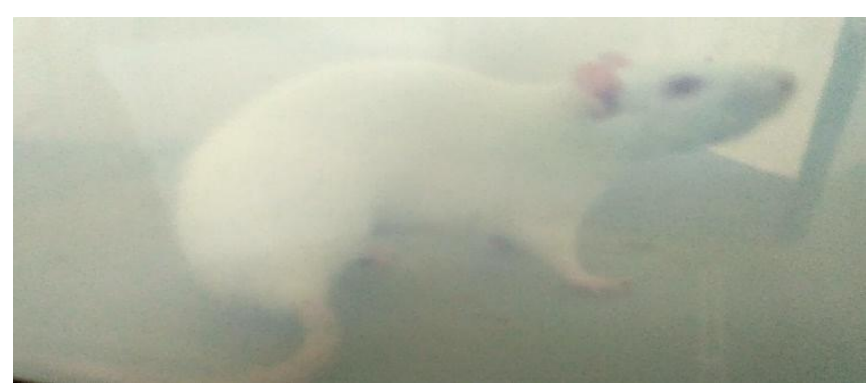

Figure: 4 Animal showing completion of writh - twisting the trunk 
Table: 2 Effect of kashaya of stem bark of Asoka - Saraca asoca (Roxb.) de Wilde on writhes induced by i.p administration of $0.25 \%$ acetic acid in normal saline.

\begin{tabular}{|l|c|c|}
\hline Group & Mean & Percentage of inhibition \\
\hline Group A(Control) & 53.08 & - \\
\hline Group B(Standard) & 31.17 & 41 \\
\hline TG1 - 1/2X & 49.50 & 16 \\
\hline TG2 - X & 32.83 & 38 \\
\hline TG3 - 2X & 16.08 & 79 \\
\hline
\end{tabular}

Values are expressed as mean, $\mathrm{n}=6$

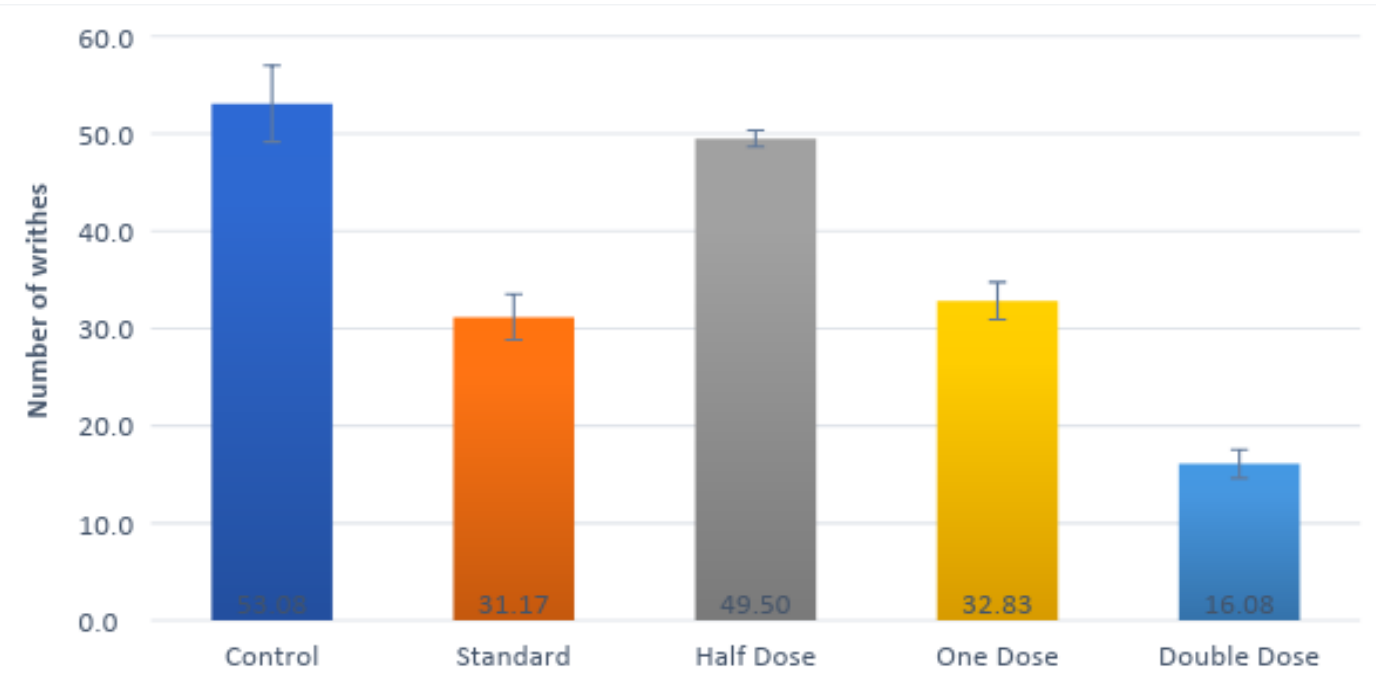

Figure: 5 Bar diagram comprising mean value of no. of writhes in each group.

\section{Analysis of data from analgesic study}

The data were subjected to statistical analysis using ANOVA with Duncan's multiple range test to draw a comparison between control, standard drug and test drug groups.

Table: 3 ANOVA table showing difference in number of writhes between groups in analgesic study

\begin{tabular}{|c|c|c|c|c|}
\hline Group & Mean \pm SE & $\begin{array}{l}\text { Percentage of } \\
\text { inhibition }(\%)\end{array}$ & F-value & p-value \\
\hline Group A & $53.08 \pm 3.921$ & - & \multirow{5}{*}{41.15} & \multirow{5}{*}{0.000} \\
\hline Standard & $31.17 \pm 2.355$ & 41 & & \\
\hline TG1-1/2X & $49.50 \pm 0.837$ & 16 & & \\
\hline TG2 - X & $32.83 \pm 1.918$ & 38 & & \\
\hline TG3 - 2X & $16.08 \pm 1.457$ & 79 & & \\
\hline
\end{tabular}

\section{Discussion}

An Analysis of variance shows that there is statistically significant difference in number of writhes between the groups. The number of writhes are significantly higher in Group $\mathrm{A}$ (control) and TG1(1/2X), whereas the number of writhes in $\mathrm{TG} 2(\mathrm{X})$ is less than $\mathrm{TG} 1(1 / 2 \mathrm{X})$ \& Group A (control). Number of writhe's in TG2(X) is almost equivalent to Group $\mathrm{B}$ (standard). The number of writhes are significantly lower in TG3 (2X) when compared to all the other groups. By using Duncan's multiple range test F-value has been found as 41.15. From this, the p-value calculated is very small which gives the level of significance as $<0.001$.

Analysis of percentage of inhibition shows that Group B (standard drug) possess $41 \%$ inhibition of writhes when compared with control, TG1 $(1 / 2 \mathrm{X})$ possess $16 \%$ of inhibition, $\mathrm{TG} 2(\mathrm{X})$ possess $38 \%$ of inhibition and the TG3 (2X) possess very high inhibition of writhes of about $79 \%$. 


\section{JMSCR Vol||06||Issue||09||Page 689-693||September}

\section{Conclusion}

The results explain the analgesic activity of kashaya of stem bark f Asoka - Saraca asoca (Roxb.) de Wilde in female Wistar Albino rats. Thus, it validates the Vedanasthapana property of Asoka.

\section{Acknowledgement}

With deep sense of gratitude and respect, I express my sincere thanks to my beloved Guide Dr. Sara Monsy Oommen MD (Ay), Professor, Dr. P.Y. Ansary, M D (Ayu.), Professor \& HOD, and to Dr. Shincymol VV, Associate Professor Department of Dravyagunavijnanam, Govt. Ayurveda College, Tripunithura, for expert guidance and timely help rendered throughout the study.

\section{References}

1. Vogel Hans Gerhard, Editor, Drug Discovery \& Evaluation: Pharmacological Assays, $3^{\text {rd }}$ edition, Springer Publication, Peripheral Analgesic Activity, page: 1031 